\title{
Teaching IELTS Writing Module through English Debate: A Case Study in Thailand
}

\author{
SUCHADA SANONGUTHAI \\ Assumption College Thonburi, Thailand
}

\begin{abstract}
Bio Data:
Suchada Sanonguthai received her B.A. in English (Second-Class Honors) from Chulalongkorn University, and is currently taking courses in the Teaching English as an International Language (TEIL) Program, Faculty of Education, Shinawatra University. After four years of teaching English at Assumption College Thonburi Thai Program, where she has been teaching since the year 2001, she was selected to represent Thailand in the AFS (American Field Service) Visiting Teacher Program at Montpelier High School in Montpelier, Vermont for 10 months. She has been the head of the English Program Academics Department at Assumption College Thonburi from the year 2007 up to present.
\end{abstract}

\begin{abstract}
The study explores how effective teaching IELTS writing module through English debate can be for 20 students in their last year in high at a private school in Thailand. The school has acquired Ms Cynthia Luo, a debate coach of the school, to teach Grade 12B academic writing course and this has made it possible for the students to brainstorm, discuss and debate over IELTS oriented issues before they start working on draft 1 and draft 2 of their essays. Three follow-up student interviews and the debate teacher interview were conducted. Active students responded positively to the use of debate in their writing class while expressing their concerns about academic vocabulary and paraphrasing skills. Passive students need more support during debate activities. Additional English activities are introduced for students' accuracy and fluency. The student participants took their IELTS mock test and their scores reflect effectiveness of debate activities in classroom while some of the students need to develop their classroom learning motivation.
\end{abstract}

Keywords: IELTS, IELTS writing module, writing Task 2, IELTS mock test, classroom debate 


\section{Introduction}

Assumption College Thonburi (ACT), a private school officially established in 1961, has been serving 5,208 students altogether from Grades 1-12 with a variety of academic programs. In the academic year $2011^{1}$ there are 306 Thai teachers and 68 foreign teachers working for ACT. The two main programs at ACT are as follows:

- Program 1: Bilingual Program which offers three core subjects including English, Science and Mathematics; partly taught in English by foreign teachers and partly taught in Thai by Thai teachers.

- Program 2: English Program which offers English, Mathematics, Science, Music, Basic Vocational, Physical Education and Health Education taught in English by foreign teachers, accompanied by Thai teachers.

Assumption College Thonburi English Program (ACTEP) was established in the academic year 2006, starting with Grade 1, Grade 4 and Grade 7. In the academic year 2009 ACTEP Grade 10 was begun for Grade 9 students of that year. Currently in the academic year 2011, Grades 1- 12 are being operated. English is used as the medium of teaching in the six subject groups; namely, Mathematics, English, Science, Health and Physical Education, Career and Technology, Social Studies and Computer Studies ${ }^{2}$ based on the Ministry of Education Curriculum 2554 B.E.

It was not until 2009 that ACTEP applied the minimum score of IELTS 5.5 as required by the Ministry of Education. This policy applied to every school in

\footnotetext{
${ }^{1}$ Thailand's academic year starts in the middle of May and ends in early March of the following year.

${ }^{2}$ From the academic year 2006 to 2010, Music was taught in English at Assumption College Thonburi. In the academic year 2011, the Saint Gabriel Foundation has introduced the Social Studies and Computer Studies curriculums in English.
} 
Thailand where English Program teaching in Grades 10-12 English was permitted to be conducted. The consequence of not being able to pass the cut-off score is that the school will not be able to certify that the student attended the English Program. It can only be recorded that they graduated from Assumption College Thonburi bilingual program where Thai is mainly used in class. This can lessen their chance of being accepted into prestigious international institutions both in and outside Thailand. The equivalent tests of the minimum score of IELTS 5.5 can be a TOEFL score of 550 (paper-based) and TOEIC score of 650.

According to an interview with the Head of the ACTEP Academics, there are three main reasons why IELTS was selected to be an exit test at ACTEP. Firstly, the test itself is recognized by more than 6,000 institutions in over 135 countries as claimed in two of the IELTS official websites. Secondly, due to the fact that two major language institutes, British Council Bangkok and IDP Education Australia Limited (Thailand) part-own the IELTS test and they both have their IELTS test locations conveniently located in downtown Bangkok, it is easy for students to attend IELTS test venues. Finally, as IELTS exams are scheduled four times a month, students are allowed to choose the date which best suits their individual college application periods at different international programs both in and outside Thailand. It is worth noting that the school pays for Grade 12 's IELTS test fee, as it is a compulsory test for Grade 12 English Program students.

Sanonguthai (2011) found that in the academic year 2010, 86.84\% of Grade 11 ACTEP students (currently Grade 12 in the academic year 2011) plan to attend an international program at the undergraduate level, $51.51 \%$ of them to Mahidol 
University International College (MUIC) and $42.42 \%$ of them to Chulalongkorn University. From the MUIC website, applicants to Mahidol University International Program are required to pass IELTS with a score of 6.5 on overall band and at least 6.0 on the writing band. With all three above-mentioned reasons and the MUIC English proficiency requirements, IELTS was selected as an exit test at ACTEP.

In the academic year 2011, ACTEP acquired Ms. Cynthia Luo as an official debate coach and Grade 12B academic writing teacher. Ms. Luo has been actively involved in debate for more than 6 years. As a speaker, she was awarded Best Speaker in The ICU Open in Tokyo, 2009, was invited to the women's exhibition debate as one of the top female speaker in Asia Pacific, and was awarded the title of National Champion three times for Best Speaker of the Grand Final and six times as Grand Finalist in National and International tournaments. As a judge, she was invited to be the Chief Adjudicator and Deputy Chief Adjudicator and judged Grand Finals many times in the region. She frequently receives invitations to coach schools / universities of the region as well.

As a Grade 12 academic writing teacher with great debate experience, Ms. Luo has designed her course as a debate training session while focusing on the IELTS Academic Writing Task 2. A report of class observation and interview conversations with Grade 12 students and the teacher, along with the students' IELTS mock test results will be presented and then discussed in later sections of this essay. 


\section{Literature Review}

The three IELTS handbooks (Harrison, M. \& Whitehead, R., 2006; Kaplan,2011; Lougheed, 2006) describe IELTS Writing Task 2 as an argumentative question. The ideas expressed in the essay should be logically organized and supported. Therefore, cohesiveness and coherence are the main focuses in the Writing Task 2 . The test takers are advised to follow certain procedures to achieve higher scores in writing for Task 2; Preparation, Drafting and Reviewing. Moreover, test takers are advised to use appropriate style and tone and employ formal vocabulary and formal grammar. Checklists for revising the writing work are provided to help the handbook readers in double checking their writing along with some sample writing models. The three main areas of scoring are task fulfillment, coherence and cohesion, and vocabulary and grammar.

Examples of questions in IELTS Writing Task 2 taken from Kaplan (2011, p. 112) are: 
You should spend about 40 minutes on this task.

You have been asked to write about the following topic.

Some people think that young people should be ambitious.

Others believe that it is fine if young people do not have big aims in life.

Discuss both these views and give your opinion.

Give reasons for your answer and include any relevant examples from your experiences.

Write at least 250 words.

You should spend about 40 minutes on this task.

You have been asked to write about the following topic.

Some countries invest a lot of money in space research. While some people believe that this money could be better used to solve other problems on Earth (for example, environmental problems), others argue that space research brings many benefits for life on Earth.

Discuss both these views and give your opinion.

Give reasons for your answer and include any relevant examples from your experiences.

Write at least 250 words. 
In a corpus-based investigation of linguistic responses to an academic writing task, Kennedy and Thorp (2007) analyzed 130 scripts responding to the same task from IELTS Academic Writing Task 2 in term of the linguistic nature of the answers at three proficiency levels: level 8 (expert user), level 6 (competent user), and level 4 (limited user). Some aspects of the characteristics of level 8 essays regarding content, relevance and coherence are as follows.

1. Statistics relating to length

$1.1239-457$ words (range of 218)

$1.226 .6 \%$ of level 8 scripts in the study consist of 5 paragraphs while $48 \%$ of level 6 scripts and $24 \%$ of level 4 scripts consist of 4 paragraphs. $10 \%$ of level 4 scripts contain only a single paragraph for the essay, compared to only $2 \%$ of those at level 6.

2. Content and internal cohesion

2.1 The total percentage of keywords from the title is $6.89 \%$, whereas at level 6 and level 4 it is nearly one third higher, at $9.97 \%$ and $9.71 \%$ respectively.

2.2 The writers list instances of detailed exemplification of main ideas.

2.3 Less frequent use of "however" than level 6

2.4 More frequent use of "therefore" than level 6 and level 4

2.5 More frequent use of additive markers (moreover / in addition / furthermore)

2.6 Less frequent use of enumerative markers (firstly / secondly / thirdly)

2.7 Less frequent use of summation markers (finally / in conclusion) 
2.8 Level 8 writers use fewer subordinators than levels 4 or 6 .

2.9 Level 8 writers are confident in showing versatility in the use of a wide range of lexis. Idiomatic language (I am all ears / prides itself / every nook and corner) is used as showed from 22 out of 30 writers.

3. Writer stance: interaction between writer and reader

3.1 Grater frequency of modal auxiliary verbs, adjectival or adverbial nominal modal expressions (e.g. possibly), modal lexical verbs (e.g. believe), and questions forms.

3.2 Writers convey their opinion more indirectly through the use of argumentation rather than stating it explicitly.

$3.340 \%$ of the writers at level 8 use questions in their text both to construct an argument and to involve the reader.

3.4 Passives are used to relate their argument.

3.5 More than 12 different emphasizers (e.g. definitely, certainly, clearly, really) and more than 20 different amplifiers (e.g. alarmingly, considerably, dramatically, enormously) are used.

It is evident in level 8 scripts that there are some additional elements found:

- the reference, by the writer, to what is assumed to be shared knowledge with the reader / examiner

- the use of personal asides to the reader/ examiner

- the use of imperatives, exclamations and extreme examples

According to the study, it is not simply grammar, structure or vocabulary which is necessary for one to score high in the IELTS Academic Writing Task 2. 
What seems to be contributing more to the writer's success is the writer's knowledge of the subject on which they are asked to give opinions and how logically these opinions can be expressed in the limited time of the test.

Westfall and McMarthy (2004) are consistently in favor of presenting some reading materials as a starting-off point for ESL students at an intermediate-level of English. Afterwards, explicit vocabulary teaching is performed, followed by discussion or debate activity. Students are then asked to work on a piece of writing, having three questions as guidelines for their topic. At the end of each chapter, students read two idioms or sayings related to the topic and another session of vocabulary teaching will commence.

The use of reading for writing in teaching academic writing has also been proposed by Shulman (2004) in order to build up critical thought in students. It is suggested that through reading, talking, and writing about news from around the world, students will become knowledgeable and gain more confidence in using new vocabulary words. The following practical skills are presented in each of the 14 chapters of the book:

1. Reading 1 with glossary

2. Discussion of Reading 1

3. Reading 2 with glossary

4. Discussion of Reading 2

5. Vocabulary

6. Research Question

7. Writing Assignment 
8. Debate

9. Thinking about It

10. Web Surfing

\section{Suggested Reading}

It is expected that this textbook will be good preparation for academic courses in which advanced students are required to use their critical thinking skills in expressing their opinions, both orally and in writing. The reading materials appearing in the book are taken from a variety of sources; BBC News, The Economist Newspaper Limited, Newsweek, etc. The debate activity is defined as having two teams present opposing arguments on a controversial topic with the aim of proving their point of view to the audience. The Pro team presents arguments in favor of a topic. The Con team presents argument in opposition to a topic. Each team has a leader who gives an opening statement and a closing statement. Students are encouraged to prepare for their debate by reading some of the books listed under the topic in each chapter entitled Suggested Reading.

The topic of Preimplantation Genetic Diagnosis (PGD) has been taught over the past several years through classroom activity debating (Staddon, 2008). The debate activity is done at the end of a unit on genetics. In this role-play debating exercise, students form a congressional committee as well as various parties who come to testify. The controversial topic is whether a law should be created governing PGD. This exercise takes three days. Day one is for background and preparation with support from teachers in getting students to consider various points of view surrounding PGD. Day two is for each party to present its position to the 
congressional committee. After each presentation, the congressional committee asks questions of each group. Students are told that their grades will be based on the amount of support it receives from the students' peers. On Day three, students read all the laws and rank each party according to how much the laws support their arguments. This encourages students to consider the attitudes of their peers.

Johnson (2009) stated that critical thinking can be achieved through debate. The fact that debaters always work with claims, supports and interferences makes debate different from other language speaking activities. At the same time, debaters will develop "a strategy of control" by focusing on determining, designing and directing what happens in the round. Debates which are controversial and require argumentative reasoning that contributes to the analytical process of both the depth and breadth of the arguments. The form of argument can be presented with these three models:

Figure 1. Simple Model from Johnson (2009, p. 19)

Claim

\section{Support}

Euthanasia for terminally ill patients should be legalized

Upon death, the terminally ill patient's suffering ceases 
Figure 2. Chain Model from Johnson (pp. 20-21).

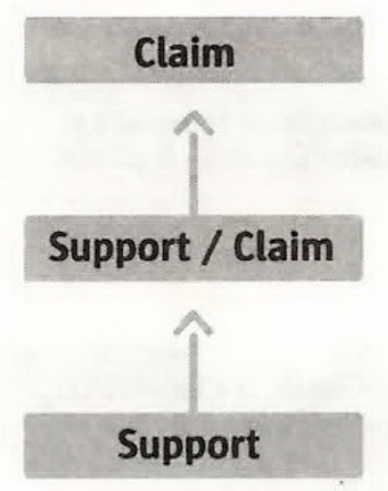

Euthanasia for terminally ill patients should be legalized

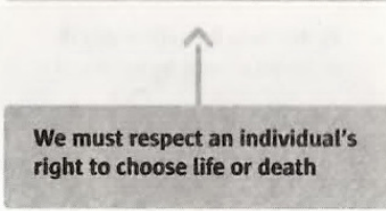

Individual autonomy is an essential element of humanity

Figure 3. Cluster Model from Johnson (pp. 21- 22).

\section{Support}
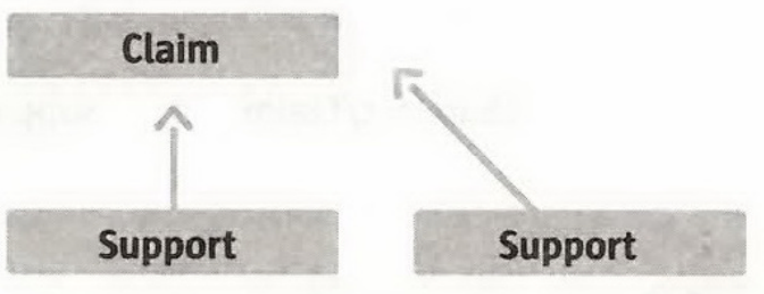

Euthanasia for terminally ill patients should be legalized

We must respect an individual's right to choose to live or die
Upon death, the terminally ill patient's suffering ceases
Euthanasia relieves the family's financial burden 
Figure 4. Complex Model from Johnson (pp. 22-23).

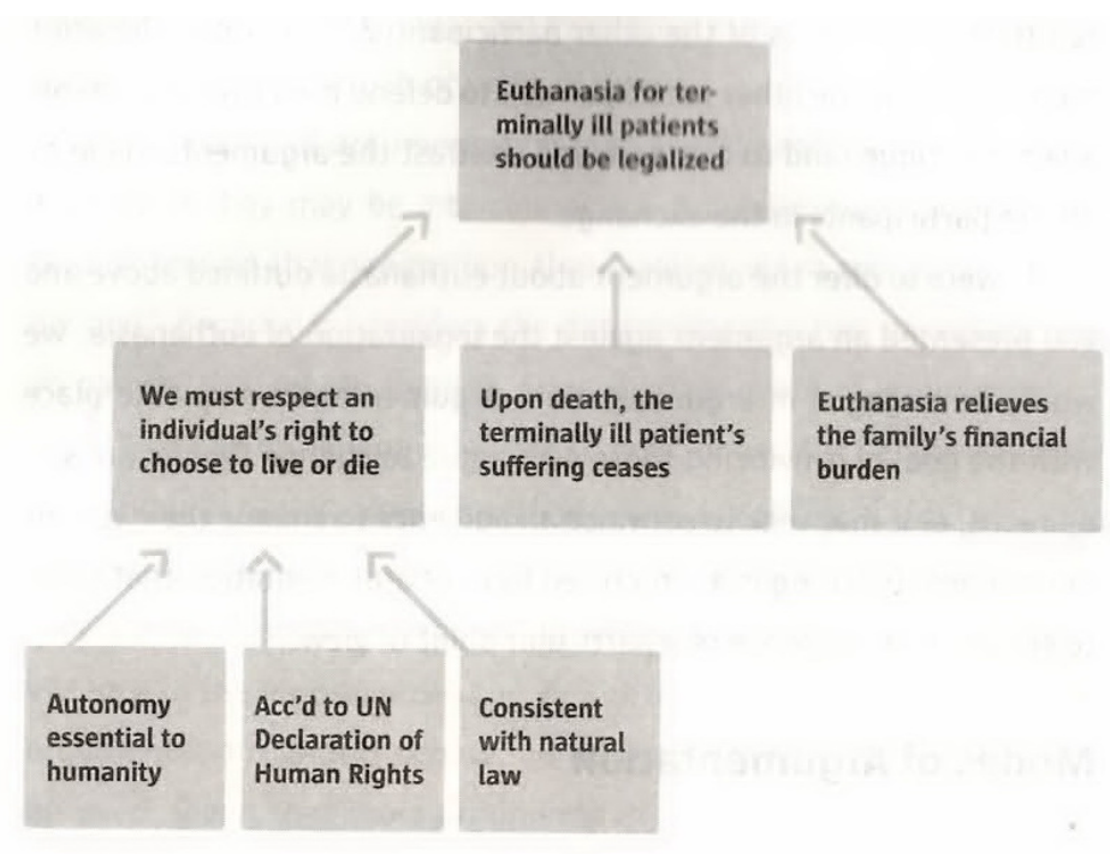

\section{Methodology}

Grade 12B's IELTS Academic Writing Task 2 lesson which lasts 3 hours was observed and followed by after-class-observation interviews with Grade 12B students and the teacher.

\section{Brainstorming as a Whole Class}

On the day of the class observation which occurred in Week 8 of the academic year 2011, the topic of Advertisement was being discussed. However, the class started with a reminder for students who had not submitted their IELTS Writing Task 1 and some emphasis on the essay format. The teacher then let the students know the topic of the day's class discussion and showed the PowerPoint presentation used in the brainstorming and discussion sessions. 
Figure 5. PowerPoint presentation on the topic of Advertisement in Grade 12B class.

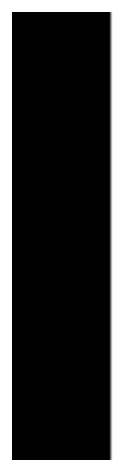

Advertisement
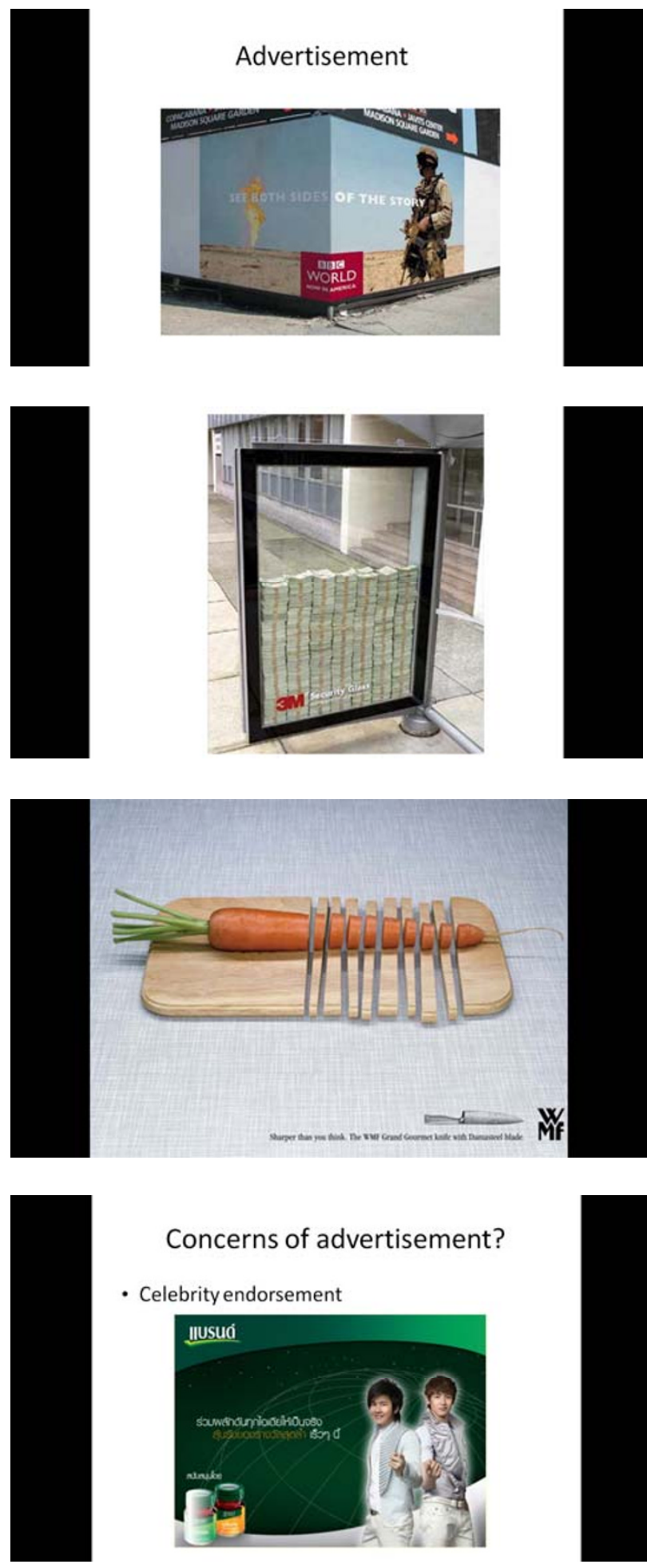

\section{Concerns of advertisement?}

- Celebrity endorsement
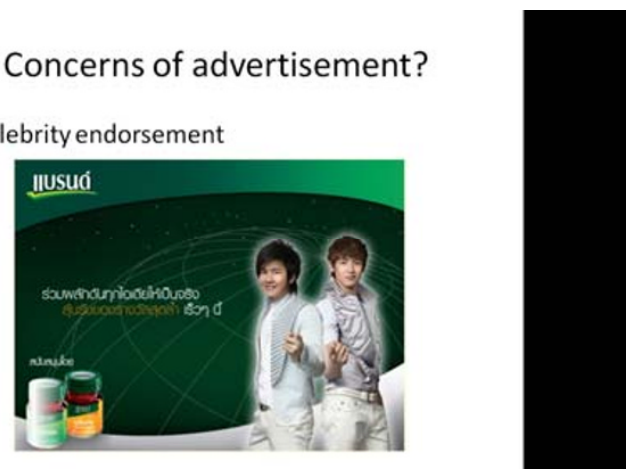

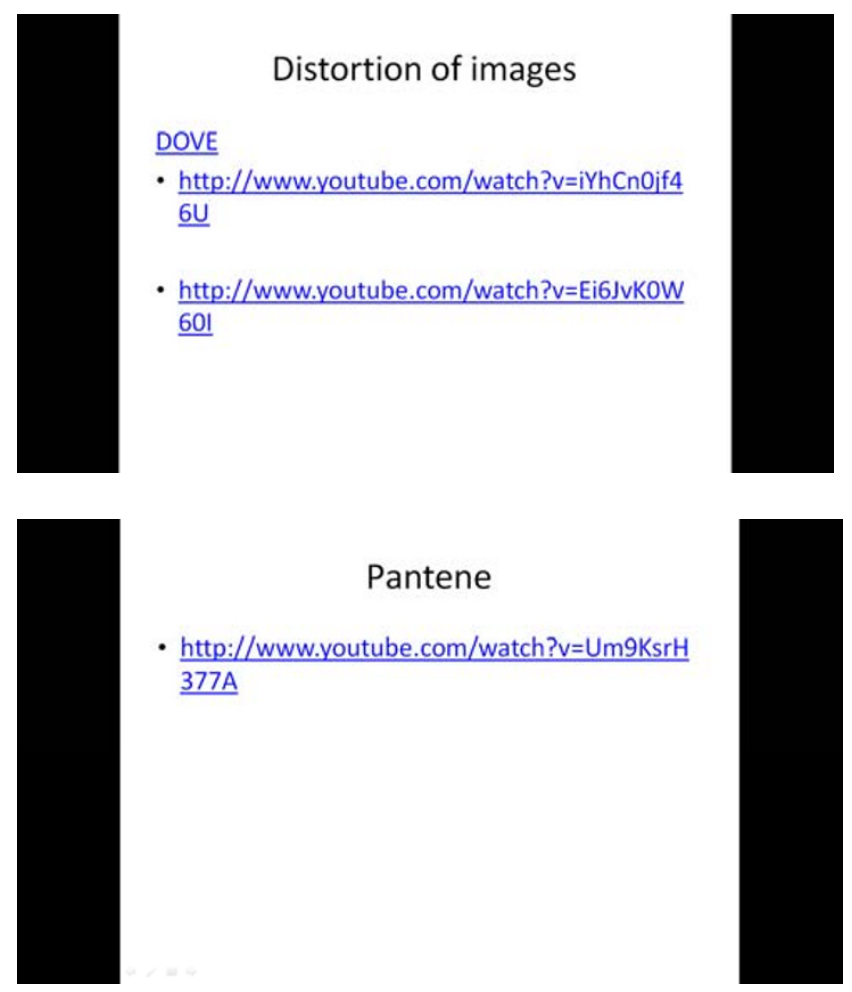

\section{Pantene}

- http://www.youtube.com/watch?v=Um9KsrH 377A

The teacher's main role here is to share necessary knowledge, arguments and perspectives beforehand with the students through the use of the PowerPoint presentation. This brainstorming session of the big groups gave them some ideas of various perspectives regarding the topic. The students gained knowledge about some concerns of advertising; celebrity endorsement, overstatement, and distortion of images. Through the observation of class discussion more than 50 percent of the students seemed to have their own views whether they wanted to be on the Pro or the Con side of the argument.

\section{From Brainstorming as a Whole Class to Debating as a Team}

The students were divided into two debating teams, comprised of 10 students in each team. The teacher balanced active students with passive students in each group. To ensure the inattentive students participated in the group discussion, the teacher chose two weak students and one strong student as representatives, so the rest of the group members had to make sure the weak students participated in the discussion 
or at least understand the discussion. The strongest member of each team was asked to be the debate leader of the group and speak first. Before their debating session ended this same leader was asked to summarize the ideas of their Pro or Con team.

During the debating activity, the teacher moderated the session, re-phrased their points into better sentences, inspired them to further extend and analyze the points, and explained the points to the class again if necessary.

\section{From Debating as a Team to Writing as an Individual}

After the lesson entitled "Advertisement" was completed, the students were assigned to write an essay related to the subject matter "The Pros and Cons of Advertising" which was due one week following the lesson. These two slides were showed to the students for clarification.

Figure 6. Clarification on Essay assignment.

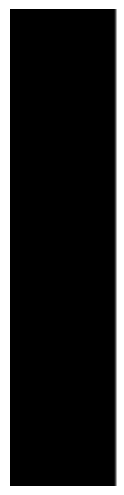

- Advertising is all around us, it is an unavoidable part of everyone's life. Some people say that advertising is a positive part of our lives while others say it is negative.

- Discuss both views and give your own opinion. Give reasons for your answer and include any relevant examples from your own knowledge or experience. You should write at least 250 words.

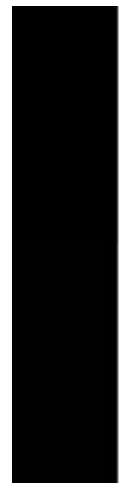

\section{Essay Format}

- Must have:

- Essay code, e.g. Week8_Advertisement (header)

- Your class, class number, nickname, full name (header)

- Name your own essay title e.g. corporal

punishment is not justified

-2.5 spaces, 250 words- 350 words

- E.g.
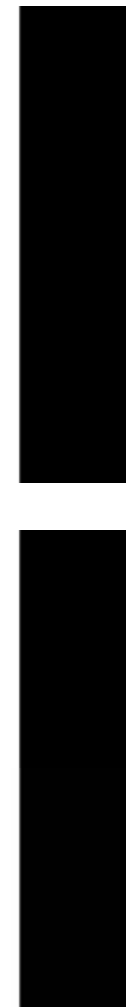
The students were encouraged to double check their own work, using Microsoft word spelling and grammar check. Following this, their first draft was given to one of their friends for peer-review. Parents were allowed to become involved by reviewing the students' first or second drafts. At the end of the process, the students were asked to correct any mistakes, print it out, and submit their work when class met again the following week.

\section{Interviews with Three Groups of Students}

Three follow-up student interviews and the debate teacher interview were conducted. The participants in the first three interviews consisted of 20 students from Grade 12B who completed the study of IELTS Task 2 writing through English debate. The three interviews with each group were scheduled for the next day after the lesson, lasting about 25 minutes for each group.

The students were divided into three groups based on the final grade of their former English writing course obtained in their previous school year. The details of the student's final grades are:

Table 1

Details of each Grade 12B's Grade 11 Writing Final Grade

\begin{tabular}{|l|c|}
\hline Student & Grade 11 writing final grade (out of \\
No. & $100 \%)^{*}$ \\
\hline Student 1 & 79 \\
\hline Student 2 & 80 \\
\hline Student 3 & 79 \\
\hline Student 4 & 76 \\
\hline
\end{tabular}




\begin{tabular}{|l|c|}
\hline Student 5 & 60 \\
\hline Student 6 & 81 \\
\hline Student 7 & 60 \\
\hline Student 8 & 70 \\
\hline Student 9 & 57 \\
\hline Student 10 & 82 \\
\hline Student 11 & 80 \\
\hline Student 12 & 78 \\
\hline Student 13 & 74 \\
\hline Student 14 & 83 \\
\hline Student 15 & 80 \\
\hline Student 16 & 76 \\
\hline Student 17 & 56 \\
\hline Student 18 & \\
\hline Student 19 & \\
\hline Student 20 & \\
\hline
\end{tabular}

*arranged in the order of student ID number

Table 2

Three Groups of Participants in the Follow-up Interviews

\begin{tabular}{|c|c|c|}
\hline Group & $\begin{array}{lll}\text { Grade } 11 \text { Writing Final } \\
\text { Grade } & & \\
\end{array}$ & $\begin{array}{l}\text { Numbers of } \\
\text { Students }\end{array}$ \\
\hline A & $80 \%$ and above & 8 \\
\hline
\end{tabular}




\begin{tabular}{|l|c|c|}
\hline B & $66 \%-79 \%$ & 7 \\
\hline C & $50 \%-65 \%$ & 5 \\
\hline & Total numbers of & 20 \\
& participants & \\
\hline
\end{tabular}

The interview questions were open-ended which aimed to find out how effective a debate activity in class was for the students in each group and how they perceived the advantages and disadvantages of debating with the focus on the IELTS Writing Task 2.

The topic areas discussed in the interviews were:

- Advantages and disadvantages of a class debate activity In response to this topic Group A expressed that they learned a lot of argumentative skills and ways to balance and win the opposite party's argument. They enjoyed every debate session as it brought new ideas which were useful for their writing. They did not see anything wrong in using debates as the main activity before they started writing their IELTS Task 2 essay of the related topic. Group B also enjoyed their debate class for the same reason as Group A and they found that debate was an interesting and challenging activity for them. Three out of five students in Group C however, expressed that it was quite difficult for them to follow the brainstorming session even with the use of PowerPoint until they got together in their debating team and their team members used Thai to explain what was expected of them. 
- English skills practiced through debating

Group A liked the way the teacher gave techniques in debating and found that they could practice their speaking skills at the time of debating. They felt the need to listen to their friends carefully so that they could respond to their arguments. Group B reported that they had practiced listening skills, speaking, and also writing as they needed to take notes quickly on claims they heard and ways they wanted to defend their arguments when it came their turn to debate.

- English skills lacking through debating

Group A and Group B expressed their concerns regarding the lack of academic vocabulary in their debating. Even though the teacher had a wide range of words and was able to express the arguments clearly, the students did not get to use new vocabulary until they started writing their own essays. Group A in particular would have liked to have learned more paraphrasing skills as many times their complete paper was not accepted by the teacher because they had plagiarized in their research. Group C reported that they tried their best to debate for their team, but most of the time they did not respond to the opposite's team arguments because they did not quite understand the academic vocabulary. Two students in Group C found it was helpful when the teacher rephrased what they said in the debate because they learned how to speak the same message in a more appropriate and wellstructured sentence. 
In addition to the above summary of interviews, Group A students complained about checking too many of their classmates' essays which were given to them in the last minute before the submission due date. Moreover, Group B wished that they could get the teacher's feedback of their writing sooner than two weeks. Every student in Group C complained about the amount of writing assignments, about one every two weeks.

The interview with Ms. Luo, the debate teacher, was scheduled in the afternoon on the same day of the interviews with the students. The interviews lasted 90 minutes. The interview report is presented below.

- $\quad$ The debate teacher's belief about the IELTS writing as a fair screening test for university

The teacher expressed that IELTS was designed to test whether the test taker can adapt to an English speaking classroom or society. For this reason, it tests and evaluates the test takers' overall English ability. Through effective IELTS oriented English classes, the students should be able to improve their English at a relatively quick pace. However, the line for the IELTS score needed to be drawn at "ready for English Speaking University", in her opinion, to at least 6.5 overall and no sector should be lower than 6.0 .

- $\quad$ Course topics and content focusing on Writing Task 2 IELTS Academic Writing Module

The teaching and exercises used for Grade 12B were designed based on academic writing's requirements but featured debate's tactics and perspectives. She generally led in the brainstorming with some predominating points of view, based 
on the group's thoughts when talking about the certain topic. Once the students were on the thread of the common views then she would surprise them with distinctive arguments for the opposite side or the critical questions that challenged the dominating opinions. Then she left the students to expand the arguments or more often to illustrate the arguments according to the logical steps.

- $\quad$ The definition of debate in the teacher's writing course teaching in Grade 12B

The debate exercises used in Grade 12B were still very elementary in her opinion. She divided the class into 2 groups, balanced active students with passive students, then assigned each group either affirmative or negative sides and asked them to prepare at least 3 reasons to support their point of view. She also assigned 3 students from each group to present the ideas. To ensure the inattentive students participated in the group discussion, she often chose 2 weak students and 1 strong student to present.

The debate topics that she used in the class were all from the pool of IELTS exam topics. She preferred more controversial issues as they generated better discussion. The other primary factors were the difficulty of the topics and the specific knowledge the topics required. She used simple issues from students' daily life to familiarize them with the discussion style. After several classes, she would introduce the topics with specific knowledge relating to the background of the issues and explain the existing views on the topics e.g. global warming, overpopulation, space exploration etc.

- Debate in relation to student's sentence writing ability 
When the students presented their ideas, she often had to re-phrase their words into an argument with better construction and she asked them to repeat exactly as she said. After a few sessions, she realized the English foundations of the students were not good enough to write coherent ideas. More severely there was a large portion of the students who lacked basic English skills. To strengthen the ability in writing proper sentences, she added Band 9 essays/paragraph dictation and analysis, introduced 100 "must recite" sentences into the class and worked with the students in pairs, especially with those weaker in English. They had to recite the sentences to each other and to her by random checking after she explained the sample sentences structure and the vocabulary involved. After they recited the sentences, students were required to write a new sentence by adopting a similar framework.

Figure 7. Band 9 essays/ paragraph dictation and analysis.

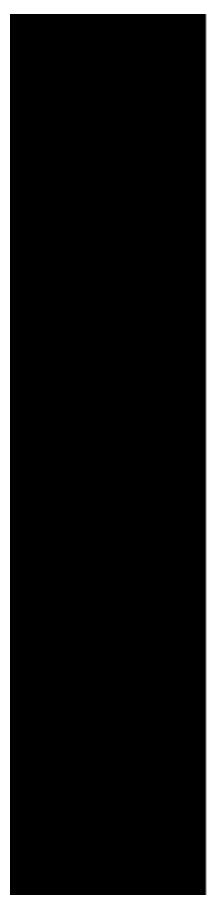

- Below is a 'band 9' paragraph about the benefits of zoos. I took the vocabulary ideas and organised them in the following way:

1. Simple topic sentence.

2. The main benefit is that...

3. Another advantage of zoos is that...

4. From a personal point of view,...

- I've underlined the band 9 vocabulary.

- Zoos have several benefits. The main benefit is that zoos play an important role in wildlife conservation. They help to protect endangered species, such as pandas or rhinos, and allow scientists to study animal behaviour. Another advantage of zoos is that they employ large numbers of people, therefore providing job opportunities and income for the local area. Also, the money that zoos make can be used for conservation projects. From a personal point of view, zoos are interesting, educational and fun. They are entertaining for families, and teach children to appreciate wildlife and nature. 
Figure 8. Samples of Grade 12B student's work.

There are several advantages for studying English language. The Main advantage is English which is the international languagev so the most people around the world absotutely can speak English. Another advantoge of studying English is that when we have to go to
another country, it will be more easily because you have

to communicate with the local people by speaking, countm listening, or writing in English lanaugag of some countr doestn't give the English to be its national Tanguage. Therefore, the most countryies afound the world set the English to be their second language such as Thailand. From a personal point of view, there is not only English is the popular language, but also Chinese, and Spanish. Nowadays, we possibly speak mone than 2 languages because in the future we will have more communications with another countryy, so it will be 'good for us 


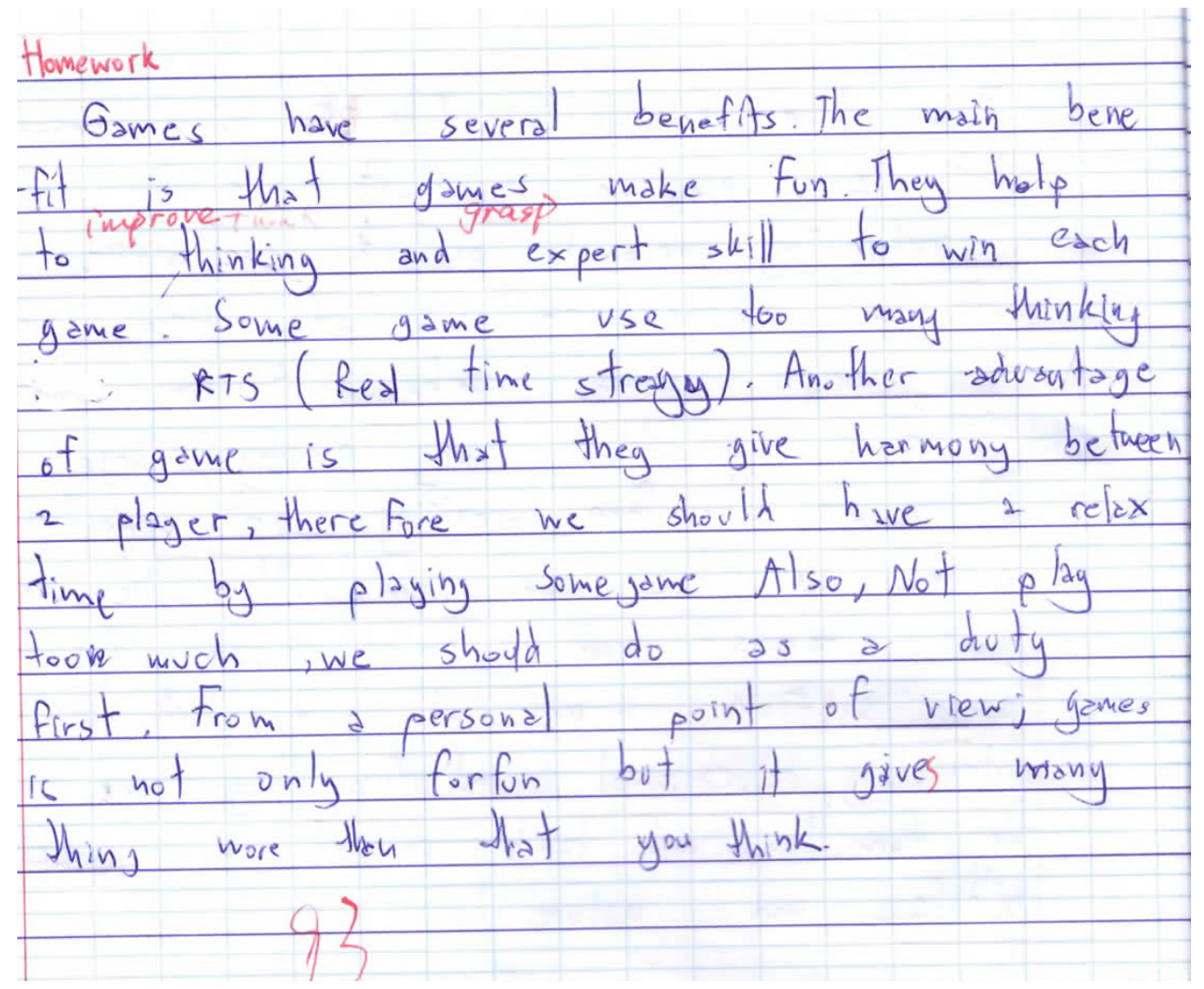

Figure 9. Sample of 100 must recite sentences structures.
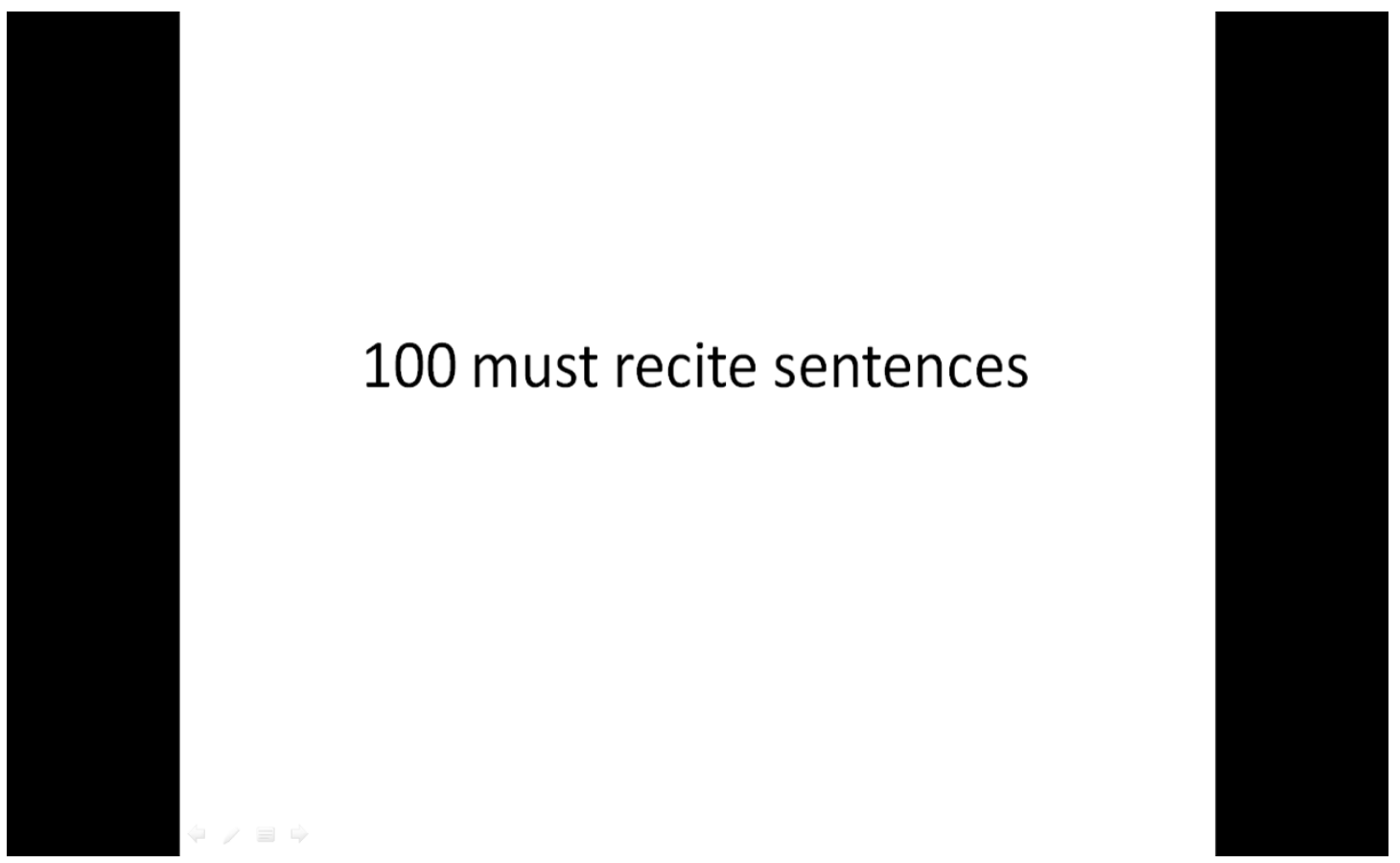


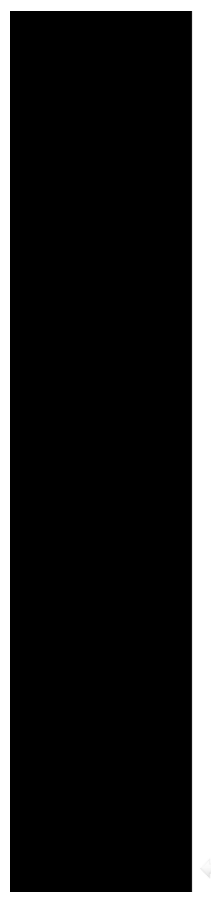

1. Typical of the grassland dwellers of the continent is the American antelope, or pronghorn.

2. Of the millions who saw Haley's comet in 1986, how many people will live long enough to see it return in the twenty-first century.

3. Anthropologists have discovered that fear, happiness,

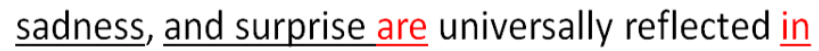
facial expressions.

4. Because of its irritating effect on humans, the use of phenol as a general antiseptic has been largely discontinued.

5. In order to remain in existence, a profit-making organization must, in the long run, produce something consumers consider useful or desirable.

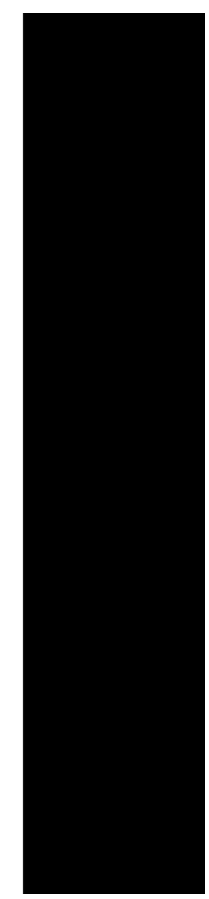

Figure 10. A Sample of Grade 12B student's work

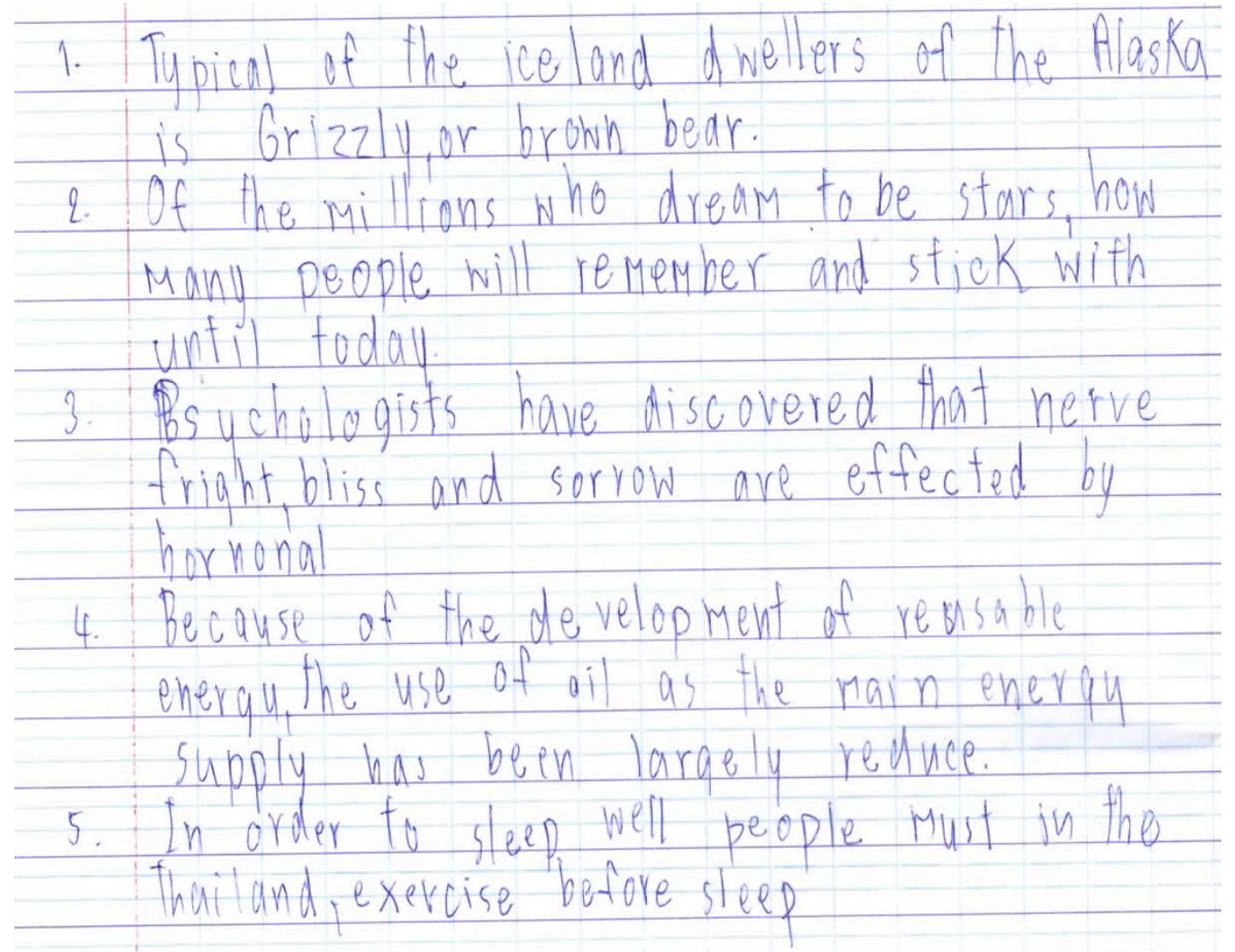

- Debate in relation to student's paragraph construction skills 
During debate sessions, students often gave the teacher a few small elements at different sequences. She then organized these elements under one big argument that supported the evidence or analysis. She tried to show how students could use the same method to organize the content of the paragraph so that their essays could be more coherent with a clear logic.

- Debate in relation to student's ability to remember writing frameworks Ultimately, how much a student benefited from certain teaching was determined by the individual efforts. To help students remember the structure of the sentences and paragraphs the students repeated the content the teacher wished them to remember many times. To avoid the boredom of repetition, she found letting the students write down the whole content of an audio clip of a well-written essay very effective in reinforcing the memory subconsciously. She repeated the same sentences over and over again, but students were still constantly challenged by the content they could not recognize or could not write down, so they remained alert to find out what it was. By the time they wrote down the entire sentence, she had repeated it enough times to make sure they remembered the content. On top of memorization, the tremendous improvement in their listening was noticeable within the first two attempts at dictation.

- $\quad$ Debate in relation to students' communication strategies

This is the skill that benefited the most from debate trainings directly. At the same time, this is the very skill even most adults cannot master. More than anything, in any debate or class discussion the teacher made sure the students learned bit by bit how to communicate in simple and clear language and required them to ensure 
all parties understood their points perfectly. The most common mistakes that people make in giving a speech or writing an essay is that they assume their reasons are self-proving and jump to conclusions too soon. The result is a lack of content. Highly alerted in detecting this, she required and reminded students over and over again that they needed to illustrate their reasoning in a clear step by step manner by continuously asking themselves "why" and "how" to prove the previous claim.

More skills which benefited from debating were students' critical thinking ability, analytical skills, fast thinking ability, organizational skills and presentation skills. These are all essential for the students' future development in life.

- The assessment of the course

Firstly, the students were required to finish most of their essays in Microsoft Word and use the spelling and grammar check to screen out the obvious grammatical mistakes. They then received a correction by their peers, revised their essays and wrote a second draft. Finally, they received the teacher's correction and feedback. Through many checkups they realized their weak points and paid extra attention for the following assignments.

By dividing students into small groups for discussion and competition, they needed to help each other out. Also by requiring everyone to go through essay student-correction before they submitted peer edit draft two, they were learning to be responsible to others.

\section{Assignment Grading Criteria}

Overall, these criteria were developed based on the IELTS/TOEFL academic writing scoring criteria but tailored to evaluate student's efforts and motivate students to 
develop their critical thinking skills and analysis of logical structures as can be seen below:

Table 3

Assignment Grading Criteria for Grade 12B

\begin{tabular}{|c|c|c|}
\hline Efforts \& submission & 20 & $\begin{array}{l}\text { How much effort did you put in writing this } \\
\text { essay? Are there obvious mistakes that can be } \\
\text { easily fixed by yourself if you revise your } \\
\text { homework carefully? Did you submit your work } \\
\text { on time? Did you follow the correct format? }\end{array}$ \\
\hline Grammar & 20 & How good is the grammar of your essay? \\
\hline Vocabulary & 20 & $\begin{array}{l}\text { Is the spelling correct? Did you use the correct } \\
\text { form of the words,(e.g. verb \& noun mixed up), } \\
\text { Wrong meaning of the words in the content will } \\
\text { cause the deduction of this score. The variety of } \\
\text { words used can be an addition to this part of the } \\
\text { score. }\end{array}$ \\
\hline Structure \& Logic & 20 & $\begin{array}{l}\text { How logical did you lay out your ideas? Is it } \\
\text { coherent to the main idea? }\end{array}$ \\
\hline Content & 20 & $\begin{array}{l}\text { How thoughtful your ideas are, the depth of } \\
\text { your analysis, how is your clarity in your } \\
\text { writing, did you write closely according to the } \\
\text { topic }\end{array}$ \\
\hline Total & 100 & \\
\hline
\end{tabular}


The following table shows the results of each student's marking grade for their Advertisement essay.

Table 4

Score Results of Each Student's Marking Grade for their Advertisement Essays

\begin{tabular}{|l|l|}
\hline Student No. & Score on the Advertisement essay \\
topic \\
\hline Student 1 & 81 \\
\hline Student 2 & 81 \\
\hline Student 3 & Plagiarism \\
\hline Student 4 & 83 \\
\hline Student 5 & 0 (Not submitting any work) \\
\hline Student 6 & 83 \\
\hline Student 7 & 0 (Not submitting any work) \\
\hline Student 8 & 0 (Not submitting any work) \\
\hline Student 9 & 0 (Not submitting any work) \\
\hline Student 10 & 83 \\
\hline Student 11 & 82 \\
\hline Student 12 & 78 \\
\hline Student 13 & 79 \\
\hline Student 14 & 80 \\
\hline Student 15 & 85 \\
\hline
\end{tabular}




\begin{tabular}{|l|l|}
\hline Student 17 & 0 (Not submitting any work) \\
\hline Student 18 & 0 (Not submitting any work) \\
\hline Student 19 & 80 \\
\hline Student 20 & 90 \\
\hline
\end{tabular}

A month after the lesson observation, the students were given a mock test run by a qualified teacher who had experience with IELTS. All the students in Grade 12B took this test and the following results show how each students did in their Task 2 writing and their overall band scores. Below are an IELTS Writing Task 2 question and the Grade 12B students' Writing Task 2 scores and their overall band scores.

Figure 11. The IELTS mock test Writing Task 2 question at ACTEP.

\section{Writing Task 2}

You should spend about 40 minutes on this task.

Write about the following topic:

It is generally believed that the Internet is an excellent means of communication but some people suggest that it may not be the best place to find information.

Discuss both these views and give your own opinion.

Give reasons for your answer and include any relevant examples from your own knowledge or experience.

Write at least 250 words. 
Table 5

Grade 12B Mock Test's IELTS Writing Task 2 and overall band scores

\begin{tabular}{|l|c|c|}
\hline Student No. & Task 2 Mock Test & Overall Band \\
\hline Student 1 & 6.0 & \\
\hline Student 2 & 5.5 & 6.0 \\
\hline Student 3 & 6.0 & 5.5 \\
\hline Student 4 & 6.0 & 5.5 \\
\hline Student 5 & 5.5 & 5.0 \\
\hline Student 6 & 6.0 & 6.5 \\
\hline Student 7 & 6.0 & 5.0 \\
\hline Student 8 & 6.0 & 5.0 \\
\hline Student 9 & 5.0 & 5.0 \\
\hline Student 10 & 6.0 & 5.5 \\
\hline Student 11 & 6.0 & 5.5 \\
\hline Student 12 & 5.0 & \\
\hline Student 13 & & \\
\hline Student 14 & & \\
\hline Student 15 & 5.0 & \\
\hline & & 5.0 \\
\hline
\end{tabular}




\begin{tabular}{|l|c|c|}
\hline Student 19 & 6.5 & 6.0 \\
\hline Student 20 & 6.5 & 6.0 \\
\hline
\end{tabular}

Three task 2 essays written in the mock test which belong to three students; Student No. 11 from Group A, Student No. 4 from Group B, and Student No. 5 from Group C were randomly selected and investigated. The three students were interviewed at the same time on the day they received their mock test results. The interview lasted 20 minutes. 


\title{
Figure 12. Student 11's essay in IELTS Writing Task 2 mock test.
}

\author{
"Internet" Brand Now Libraly" \\ Nowaday, intemet is the newest public techrology which provide you many information, \\ krowledge and also contain of varias kinds of enteriainment applications such as games, movies, \\ and also musics, which ypu can look yp on the sites,
}

Flecording to the topie, I thirik internet is the best place to find irformation, ard there' are two reasons that can support this opinion. Firstly, in a present time, we used internet to seareh for information, irstead of walking to the town public libraly and looking for the books that talk about the story that you want to krow. Ir addition, interret sites are also having a function to sear and search up the word that you are looking for. It is extremely fast and easy for you to find the information. For example, using site called 'Goagle' which is very famous site for searching up the vocabulary details and abo finding places and pietures. Allso, another site called 'Wikipedia' which is best on giving information and details on people status, historic events and almost everything that epo dorit understand. This site will explain it to zpo in very basic roy.

Secondly, nowaday, intemet is glabalized and spread out all over the world. We can use it to contact or communicate with otter foreign people by many applieations which provide the support for you in contracting each other. For example, the program called 'Skupe' which you can communicate with others by send text messages, use the headphione to directly talk with them and use the video comiesence to make a contact or stay in toveh with the ore who haven't meet for a long time.

In summary, I totally disagree with the topic which said that irtemet isrit the best place to fird information. The main reason is you can find everything on the intemet such as text information and also pictures that the site provide it for upu and others people that is looking for it. 
Figure 13. Student 11's IELTS mock test result sheet.

\section{Assumption College I honburi \\ English Program \\ IELTS Mock Test Score Report}

Candidate's name:

Test Results:

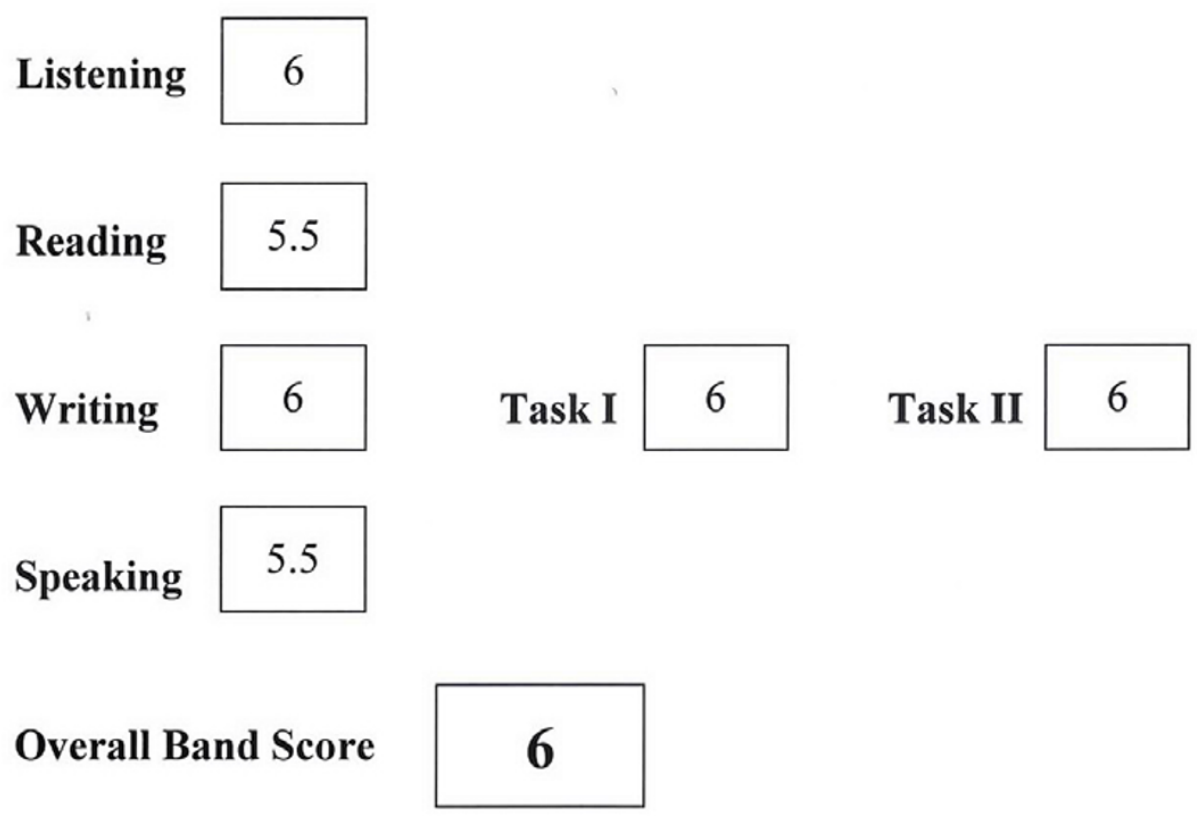

Issued Date: September 1, 2011

ACT 
Figure 14. Student 4's essay in IELTS Writing Task 2 mock test.

Nowaday, There are many technology that you can use to
communicate with other people. Some people believe that internet
is the best way to communicate with others but some people is not.
However, in my opinion the internet is the best way to communicate
with others
Firstly, In internct there are many program that you an use to talk with your frionds or family such as MSN, SKYPE, etc. You can talk with others by typing a message or you can take a video call by use the program that they hove this function. you can call to your formily when you are abroad by not pay monuy for call. You can communicate in a group such as in SkYYE we can use group video call. It make to support the business man to communicate with another co-morker.

Secondly, It can shared document to each other. It more comfortable for people who are working. They can tak and share the documents at the same time by use the same program. It easy to use more than talking to the telephone and sending a document by $\operatorname{fax}{ }^{182}$.

Thirdly, It also have social network to communicate with peopte around the world. There are many social website thot you can sign up and talk to the people around the world such as Facebook , Hi 5, My space etc. You can inake more friends not only in your country but you an make friends in another countries also. This social network can make the world smaller. You can share your opinion in the wall. You can also share your feeling with your frionds In conclusion, in my opinion internet is a group of sociely we can talk to other people by not we the telephone. There are many programs are support people to we the internet to communicate than telephone. So, infernet can make the world omaller. 306 
Figure 15. Student 4's IELTS mock test result sheet.

\section{Assumption College Thonburi}

English Program

\section{IELTS Mock Test Score Report}

Candidate's name:

\section{Test Results:}

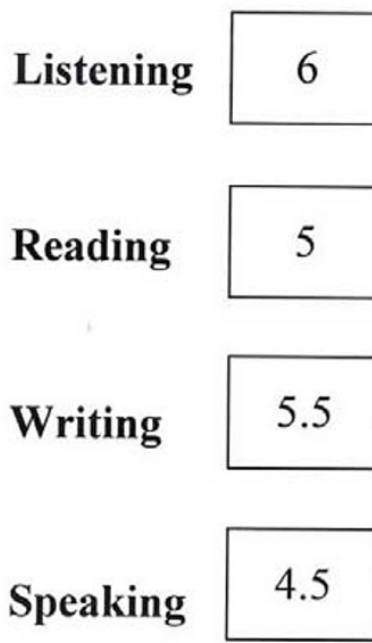

Overall Band Score

\section{5}

Issued Date: September 1, 2011

$A C T=E P$ 
Figure 16. Student 5's essay in IELTS Writing Task 2 mock test.

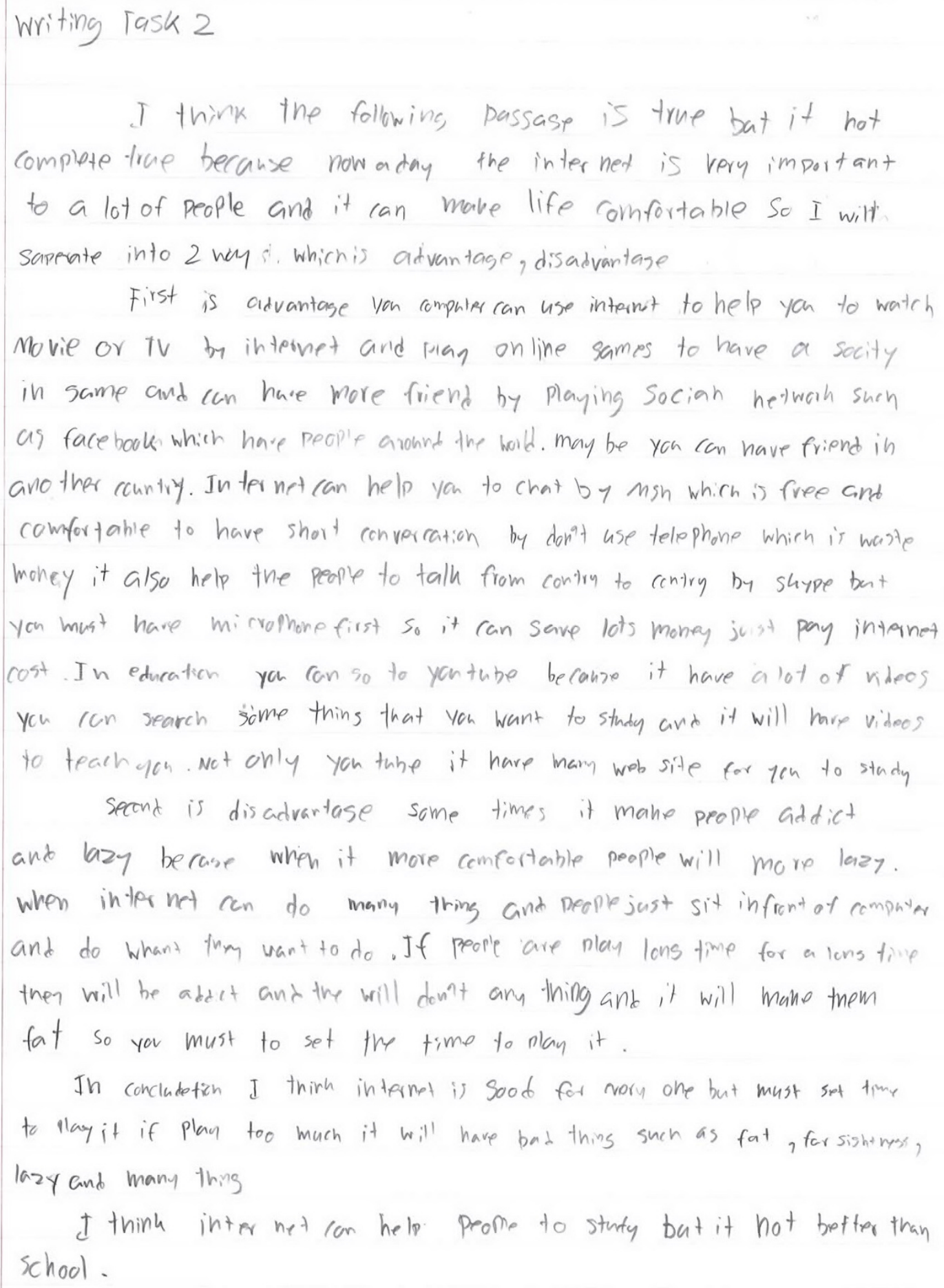


Figure 17. Student 5's IELTS mock test result sheet.

\section{Assumption College Thonburi \\ English Program \\ IELTS Mock Test Score Report}

Candidate's name:

Test Results:

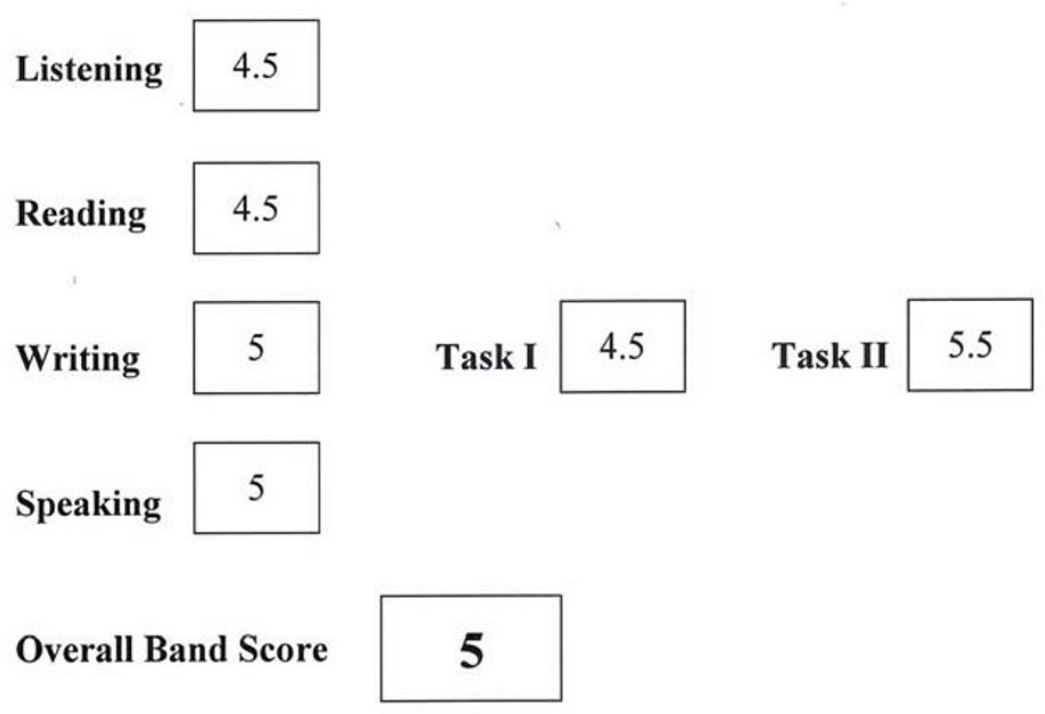

\section{Issued Daté:September 1, 2011}

All the three students agreed that debate activities in classroom had made them aware of both sides of the issue of the use of the Internet. However, Student 4 from Group B stated that he was too nervous on the day of the test, and did not express both sides of his views regarding the use of the Internet. The students reported that they were familiar with the topic in this particular Writing Task 2, the use of the Internet for information searching, but were not able to revise their essays in the given 40-minute time frame. They were however confident in expressing their 
views based on the topic given and envisioned themselves better writers for the actual IELTS test which they would be taking within the next three months.

\section{Discussion}

Through the three-hour class observation, the interview conversation with Ms. Luo and the students' mock test results, a classroom debate can be considered one of the most effective way in training the students to write better and think more critically, having IELTS Academic Writing Task 2 as their main goal. Ms. Lou's way of teaching should not be considered revolutionary, as it does encourage her students to brainstorm, draft, write, feedback, revise and edit in a cyclical fashion. However, instead of letting her students " 'think on paper' ", (as cited in Sokolik, 2003, P.97), Ms. Luo has brought the brainstorming session of her class more to a communicative approach. Her debate experience, as one student in Group A said, "has widened my (her) background in a wide varieties of topic areas from nature to technology." With Ms. Luo's careful selection of topics suited to class debates along with the 100 must recite sentences and structure exercises have provided a great opportunity for her to better the students' writing for IELTS Task 2.

The brainstorming session of the big groups and the interaction of the debate provided students much more content in relation to the topics. The debate required analysis, then helped students to illustrate the points and reasons in a clear manner. Furthermore, the debate required logic to shape their essay organization in an easily understandable order.

The fact that the essay task is similar to the IELTS Task 2 question makes the essay writing more meaningful as the students become aware that this is the same 
kind of question they will encounter on their actual IELTS writing exam. The study of Kennedy and Thorp(2007) has made us unable to simply view IELTS as focusing only on fundamental languages skills any longer. Academic debate requires a good foundation of English ability but the content of specific knowledge and level of analysis are the actual focus.

From the three students' mock test results, it is interesting to learn that Student 4, representing Group B, obtained the same Writing Task 2 score as Student 11 from Group A, while, except for listening, his other band skills are lower than Student 11 who is from the higher group. However, Student 4 might have even gained a higher score in his Writing Task 2 if he had not been so nervous that he forgot to present the negative side of his argument. Although the listening, reading and Task 1 writing scores are low for Student 5 of Group C, he could express himself quite well and received 5.5 for his essay written for the Task 2 Writing Task.

From Table 6 below, it is interesting to see that the students who did not submit their writing essays coincide with their final grade from the last school year while the students who submitted their work obtained high marks in their final draft through the process of brainstorming, debating, draft 1writing with peer review and draft 2 with the teacher's review and feedbacks.

Table 6

Comparison of Grade 12B students' scores from their last school year's writing course, their class essay on Advertisement, IELTS Writing Task 2 mock test and IELTS overall band

\begin{tabular}{|l|l|l|l|l|}
\hline Student No. & Grade 11 & Score on the & Task 2 Mock & Overall \\
& writing final & Advertisement & Test Scores & Band \\
\hline
\end{tabular}




\begin{tabular}{|c|c|c|c|c|}
\hline & $\begin{array}{l}\text { grade (out of } \\
100 \%)\end{array}$ & essay topic & & \\
\hline Student 1 & 79 & 81 & 6.0 & 6.0 \\
\hline Student 2 & 80 & 81 & 5.5 & 5.5 \\
\hline Student 3 & 79 & Plagiarism & 6.0 & 5.5 \\
\hline Student 4 & 76 & 83 & 6.0 & 5.5 \\
\hline Student 5 & 60 & $\begin{array}{l}0 \\
\text { (Not submitting } \\
\text { any work) }\end{array}$ & 5.5 & 5.0 \\
\hline Student 6 & 81 & 83 & 6.0 & 6.5 \\
\hline Student 7 & 60 & $\begin{array}{l}0 \\
\text { (Not submitting } \\
\text { any work) }\end{array}$ & 6.0 & 4.5 \\
\hline Student 8 & 70 & $\begin{array}{l}0 \\
\text { (Not submitting } \\
\text { any work) }\end{array}$ & 6.0 & 5.0 \\
\hline Student 9 & 57 & $\begin{array}{l}0 \\
\text { (Not submitting } \\
\text { any work) }\end{array}$ & 5.0 & 4.5 \\
\hline Student 10 & 82 & 83 & 6.0 & 5.5 \\
\hline Student 11 & 80 & 82 & 6.0 & 6.0 \\
\hline Student 12 & 78 & 78 & 6.0 & 5.0 \\
\hline Student 13 & 74 & 79 & 5.5 & 5.0 \\
\hline
\end{tabular}




\begin{tabular}{|l|l|l|r|r|}
\hline Student 14 & 80 & 80 & 5.0 & 4.5 \\
\hline Student 15 & 76 & 85 & 5.0 & 5.5 \\
\hline Student 16 & 74 & 0 & 6.0 & 5.0 \\
& & any work) & & \\
\hline Student 17 & 56 & 0 & 5.5 & 4.0 \\
& & (Not submitting & & \\
\hline Student 18 & 57 & any work) & & 5.0 \\
& & 0 & 5.5 & 6.0 \\
\hline Student 19 & 83 & any work) & & 6.5 \\
\hline Student 20 & 82 & 80 & & 6.5 \\
\hline
\end{tabular}

As for the students who used to do well in their last year's writing course, there is a need for a discussion which should involve the Grade 12B class teacher, students themselves and/ or parents. It is interesting to see that every student who did not turn in their essays to the teacher and Student 3 whose paper was caught plagiaristic still obtained IELTS writing task 2 scores 5.0 or over. It can be assumed that some students' motivation and their value towards school assignments need to be adjusted in a timely manner. 


\section{Recommendations}

The three students whose mock test results were studied and who were interviewed shared the same problems in the use of correct grammar and structures. Even though their opinions were presented well enough in the overall content, a higher score can only be achieved through the use of academic usage of grammar and a variety of vocabulary. If possible the school should schedule the mock test session at the beginning of every high school year and utilize the students' answer keys of every section of the test as the corpus for studying some particular grammar or structure problems. The priority of grammar topics taught in each grade's course syllabus can be predicted from major errors most students make in the mock tests.

A bigger range of vocabulary should also be taken into consideration. Reading from different sources instead of using only PowerPoint presentations can be shortcuts for the students in learning new vocabulary in context. However, a careful selection of articles is needed. Teachers might find articles from international news magazines or websites like The Economist or Newsweek more informative and argumentative than articles from unpopular websites which might be free of charge.

It would also be a good idea to do individual feedbacks which show weak and strong points of each student after they take the mock test. Because the mock test is timed and conducted in the manner of an actual IELTS test, the students should then comply with the comments or suggestions based on their performance in the mock test. This kind of feedback will be even more effective if individual discussions can occur and each student lets the teacher know how they can improve 
their skills. This kind of one on one discussion can be effective if the students are open-minded and the teacher regards them in a friendly way.

As has been proposed (Bellon, 2000), debate activities in classrooms have brought more people into the world of competitive debate. In the early 1970's, the Writing Across the Curriculum (WAC) program was introduced to promote students' ability to write. This program has been more widely adapted as Communication Across the Curriculum (CAC), and more and more universities are implementing this type of curriculum at their institute. According to Bellon, argumentativeness can bring a person to be able to "verbally" defend their opinion, and at the same time increase one's possibility to make decisions about what they will say and what they will not say (p.167). Debate is beneficial for learners in various ways as debaters will learn through their debating "explanation power", "selling power" and "Listening and Note Taking Skills" (p. 170) which are positive experiences needed for those entering the professions of law, ministry and education. It is recommended that ACTEP encourage the students who do quite well in their classroom debate to practice with the school's official debate team as it can be useful for their future career.

Due to the fact that debate skills can take a long time to practice and become good at, regular debate training is necessary for one to become a good debater. At ACTEP in particular, as many subjects are taught in English, debate training for teachers can be useful for their teaching techniques in class. If IELTS is still the ultimate goal of ACTEP's grade 12 students, it would be wise to train the students' critical thinking when they are in lower grades, not to wait until they are in high 
school and IELTS is fast approaching. As suggested by Kennedy and Thorp (2007) more focuses on the following areas of the English language are necessary for the students to get a higher score in IELTS writing task 2:

- Idiomatic language (I am all ears, prides itself/ every nook and corner)

- Various emphasizers (definitely, certainly, clearly, really)

- World or shared knowledge between the writer and the readers.

The students can only acquire these skills through their use of language and in a wide range of subject areas. The more the students expose themselves to new language items and content, the better writer they are prone to be by the time they graduate from their high school level.

Another idea is to separate ACTEP high school class B students into three groups based on their English writing performance reflected in their IELTS Writing Task 1 and 2 mock test scores. With this method, students who are good at English can develop their thinking skills through debates using more varieties of vocabulary and English structure exercises. At the same time, students with lower scores who may also have low learning motivation will be taught to value more hard work which will be beneficial for their study in a long run.

Every new school term, another mock test can be given to check whether the students should be switched to a new learning group or not. This would be done to motivate the students and help them keep track of their IELTS preparation. There is also a strong need for every student to learn more about research skills and how to write an academic essay. 


\section{References}

Bellon, J. (2000). A research-based justification for debate across the curriculum. Argumentation \& Advocacy, 36(3), 161-175.

British Council (2011, July). International English Language Testing System (IELTS). Retrieved from http://www.britishcouncil.org/thailand-exams-ielts.htm Green, A. (2007). IELTS washback in context: Preparation for academic writing in higher education. Cambridge: Cambridge University Press.

Hamp- Lyons, L., \& Heasley, B. (2006). Study writing (2nd Ed.). Cambridge: Cambridge University Press.

Harrison, M., \& Whitehead, R. (2006). IELTS practice tests with keys. Boston: Thomson. IDP Thailand. (2001, July). IELTS. Retrieved from http://www.thailand.idp.com/usa/student_services/examination_services/ ielts.aspx

Johnson, S. L. (2009). Winning debates. Beijing: Foreign Language Teaching and Research Press.

Kaplan. (2011). IELTS (2nd Ed.). New York: Kaplan Publishing.

Kennedy, C., \& Thorp, D. (2007). A corpus-based investigation of linguistics responses to an IELTS academic writing task. In S.D. Shaw, \& C.J. Weir. (Eds.), Examining writing: Research and practice in assessing second language writing (pp. 316-370). Cambridge: Cambridge University Press.

Mahidol University International College. (2011, July). Addmission requirements. Retrieved from http://www.muic.mahidol.ac.th/eng/?page_id=1633 
Nunan, D. (2003). Methodology. In D. Nunan (Ed.), Practical English Language Teaching (pp 3-22). Singapore: Mc Graw Hill.

Parcher, J. (1988). The value of debate. Adapted from The report of the Philodemic Debate Society. Retrieved from http://www.principlestudies.org/docs/The_Value_of_Debate_Secular.pdf Shulman, M. (2004). Thinking critically: World issues for reading, writing and research. Michigan: The University of Michigan Press.

Sokolik, M. (2003). Writing. In D. Nunan (Ed.), Practical English Language Teaching (pp. 87-108). Singapore: Mc Graw Hill.

Staddon, W. (2008). A classroom activity debating the ethical issues of preimplantation genetic diagnosis: A role-playing exercise. The American Biology Teacher, 70(5), 284-287.

Sanonguthai, S. (2011). The washback of the IELTS on the Assumption College Thonburi English Program (ACTEP). Language Testing in Asia, 1(2), 19-47. Retrieved from http://www.languagetestingasia.com/current-issue/lta_julyissue/

Swain, M. (2001). Examining dialogue: another approach to content specification and to validating inferences drawn from test scores. Language Testing , 18(3), 275302.

Westfall, M., \& McMarthy, J. (2004). Great debates: Language and culture skills for ESL students. Michigan: The University of Michigan.

Widodo, H. P. (2006, June). Teaching cooperative writing. Guidelines, 28(1), 27-32. 


\section{Appendix}

Appendix A: List of interview question (adapted from Green, A. (2007) Appendix 4 Teacher Questionnaire pp. 323-331)

\section{IELTS Writing Course Teacher Interview Questions}

\section{About your professional background}

Name:

Age:

Sex:

Professional Qualifications

\section{Experience}

Years experience in EFL

Experience of IELTS preparation

courses

Experience of other academic writing

teaching

Do you consider the IELTS writing to be a fair screening test for university? Why?

How is teaching IELTS writing preparation different from other classes you have taught? 
Course Topics and content focusing on Task 2 IELTS Academic Writing Module.

Describe the definition of debate in your writing course teaching in Grade 12B.

To what extent do you think the topics and content of the course were influenced by the IELTS Writing Task 2 test?

Very much

Not at all

\begin{tabular}{|l|l|l|l|l|}
\hline 5 & 4 & 3 & 2 & 1 \\
\hline
\end{tabular}

Please explain more regarding your selection of topics for argumentative discussion or debate in your $12 B$ class.

What other factors influenced the choice of course content and debate topics.

Class followed the book Class did not follow the book

\begin{tabular}{|l|l|l|l|l|}
\hline 5 & 4 & 3 & 2 & 1 \\
\hline
\end{tabular}


Please identify the book if your class followed the book.

How advanced students, intermediate students, low- intermediate students and beginner students are put together in working on a debate session.

Explain what kind of roles you take during each debate session.

How debate activities can relate to the student's Task 2 writing skills

\section{Balance of skills development through debate activities}

Discourse level skills

Sentence level skills

Please give more details

\begin{tabular}{|l|l|l|l|l|}
\hline 5 & 4 & 3 & 2 & 1 \\
\hline
\end{tabular}




\begin{tabular}{|l|l|l|l|l|}
\hline 5 & 4 & 3 & 2 & 1 \\
\hline
\end{tabular}

Please give more details.

Skills with a use beyond the course requirements

\begin{tabular}{|l|l|l|l|l|}
\hline 5 & 4 & 3 & 2 & 1 \\
\hline
\end{tabular}

Please give more details.

To what extent do you think the balance of skills development was influenced by the IELTS test?

Very much

Not at all

Please give more details.

\begin{tabular}{|l|l|l|l|l|}
\hline 5 & 4 & 3 & 2 & 1 \\
\hline
\end{tabular}


How did a debate influence the balance of skills development in the class?

Very much

Not at all

\begin{tabular}{|l|l|l|l|l|}
\hline 5 & 4 & 3 & 2 & 1 \\
\hline
\end{tabular}

Please give more details.

What other factors influenced the balance of skills development in the class? How did you deal with it?

Some benefits students gained through debate activities regarding their listening/ speaking / grammar/ vocabulary skills.

Some areas need to be considered in teaching IELST Task 2 Academic Writing Course through debate 


\section{Assessment on the course}

Students evaluated each other's work

Students did not evaluate each

other's work

\begin{tabular}{|l|l|l|l|l|}
\hline 5 & 4 & 3 & 2 & 1 \\
\hline
\end{tabular}

Students assessed their own work

Students did not assess their own work

\begin{tabular}{|l|l|l|l|l|}
\hline 5 & 4 & 3 & 2 & 1 \\
\hline
\end{tabular}

How did IELTS influence the assessment of student work?

What other factors influences the assessment of student work? 
Appendix B: Samples of Grade 12B No. 11students' essay writing on the Advertisement topic (first draft, second draft and the pint-out version for submission) 


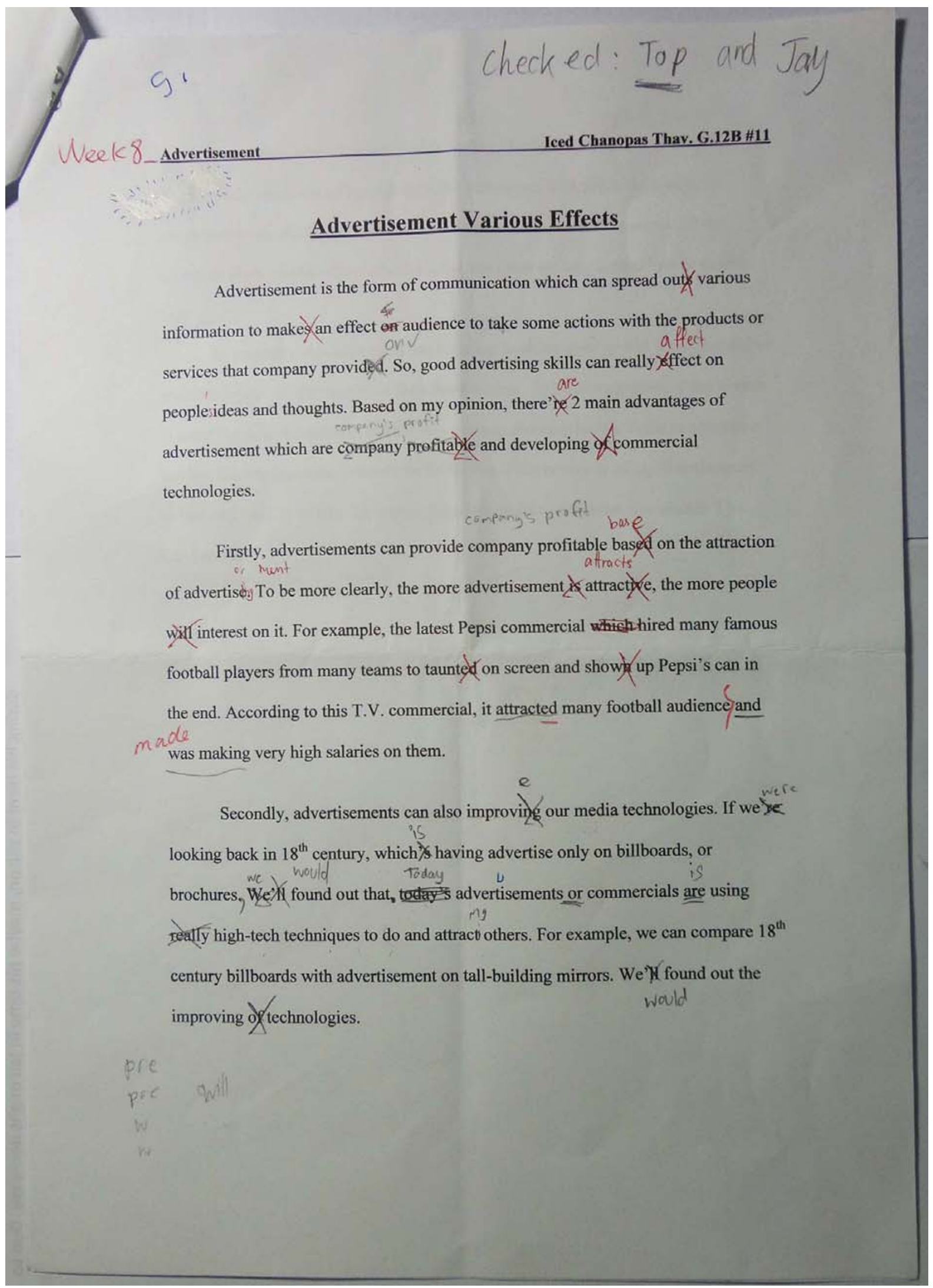




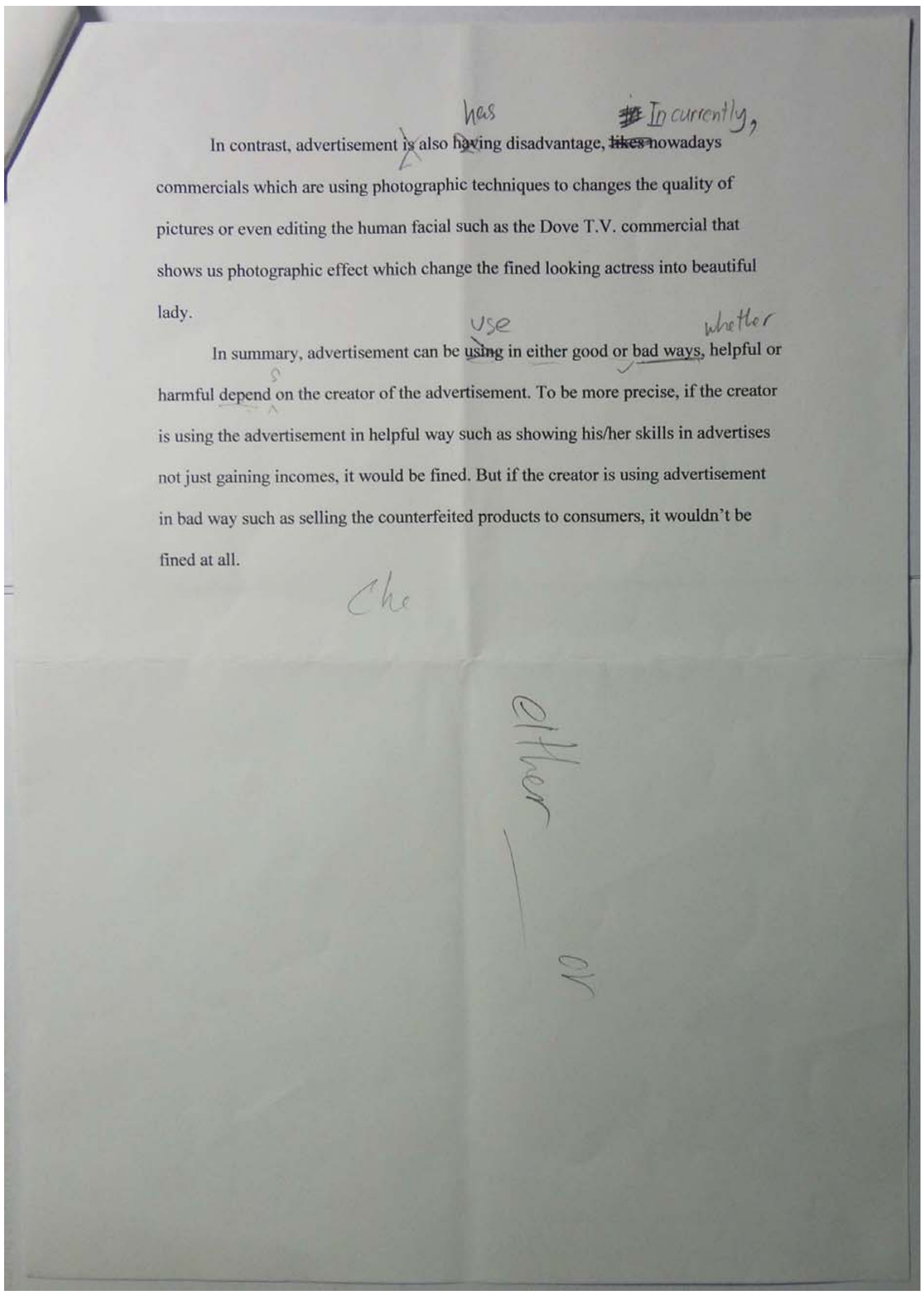




\section{Advertisement Various Effects}

Advertisement is the form of communication which can spread out various information to make an effeet-on audience to the some aetions with the products or information to make an effeet-on audience to the some aetions with the products or positively services that company provide. So, good advertising skills can really affect on people's ideas and thoughts. Based on my opinion, there are two main advantages of advertisement, which are, company's profit and development of commercial technologies. increasing

$$
\text { increase sales by adding }
$$

Firstly, advertisements can provide company's profit base on the attraction of the rroduct attractive the interest on it. For example, the latest Pepsi commercial hired many famous soccer players from many teams to taunt on screen and showeap Pepsi's products in the end. According to this television commercial, it attracts many soccer audiences and made a lot of money from the sales. very high salaries on them.

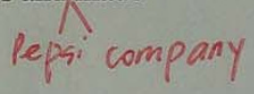

$$
\text { help to }
$$

Secondly, advertisements can also improve our media technologies. If we we can only see advertisements in the form of
in $18^{\text {th }}$ century, which is having advertises only on billboards, or were looking back in $18^{\text {th }}$ century, which is having advertises only on billboards, or
brochures, we would found out that, today advertisements or commercials is using brochures, we would found out that, today advertisements or commercia
out ract if high technology techniques to do and attracting others. For example, we can compare modern

$18^{\text {th }}$ century billboards with advertisementyon tall-building mirrors. We would found out the improving technologies. has improved dralinatically. 


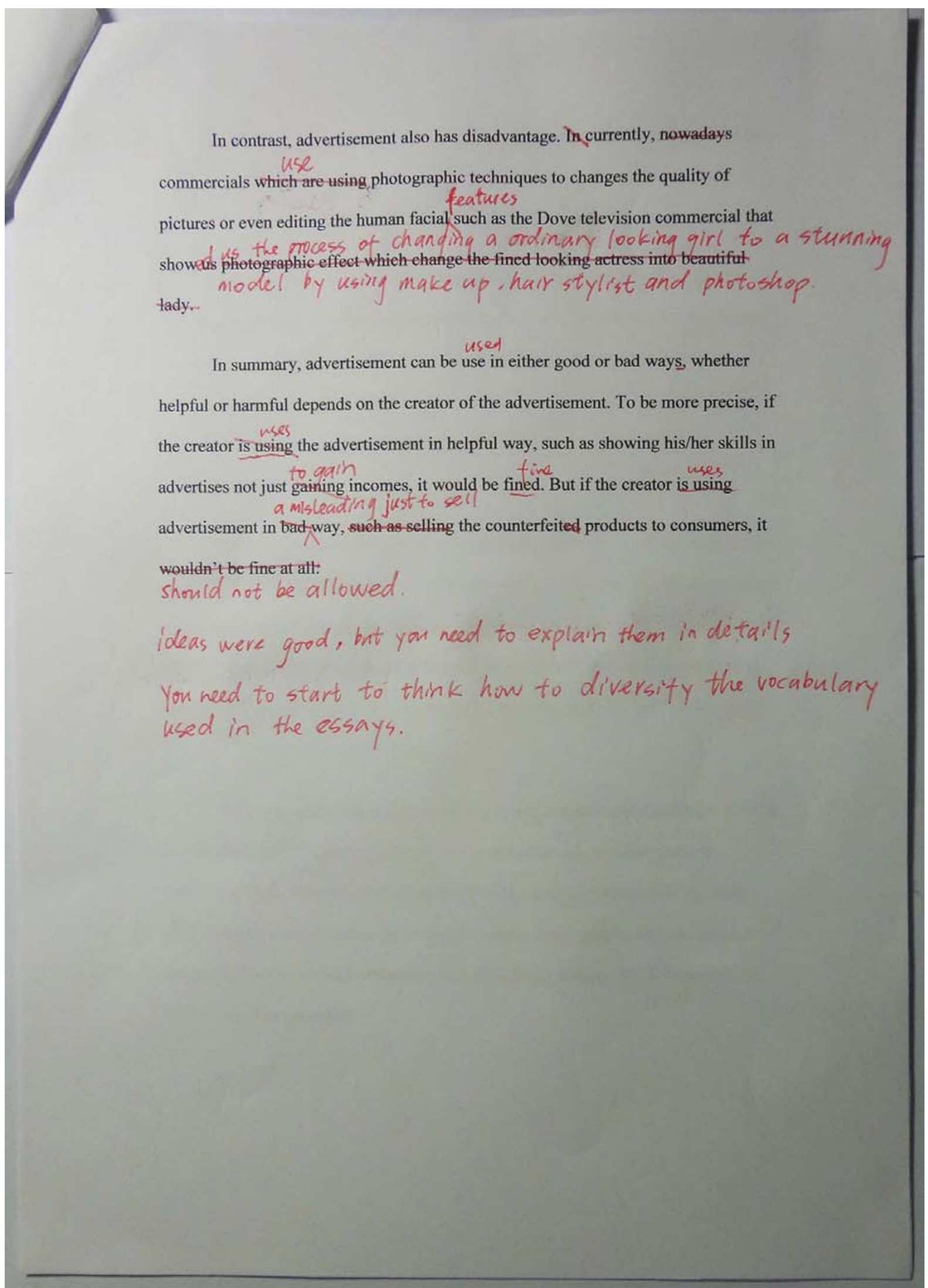




\section{Advertisement Various Effects}

Advertisement is the form of communication which can spread out various information to influence audience to think of the products or services that company provide positively. So, good advertising skills can really affect people's ideas and thoughts. Based on my opinion, there are two main advantages of advertisement which are increasing company's sales and developing commercial technologies.

Firstly, advertisements can increase company's sales by adding the attraction of the product. To be clearer, the more attractive the more people buy. For example, the latest Pepsi commercial hired many famous soccer players from many teams to on screen and show Pepsi's products in the end. According to this television commercial, it attracts many soccer audiences and Pepsi Company made a lot of money from the sales.

Secondly, advertisements can help to improve our media technologies. If we were looking back to $18^{\text {th }}$ century, we can only see advertisements in the form of brochures, we would found out that, today advertisements or commercials are using high technology techniques to out tract others. For example, it compares $18^{\text {th }}$ century billboards with modern advertisements on tall-building glass walls. We would found out the technologies has improved dramatically.

In contrast, advertisement also has disadvantage. Currently, commercials use photographic techniques to changes the quality of pictures or even editing the human facial features such as the Dove television commercial that showed us the process of changing an ordinary looking girl to a stunning model by using make up, hair stylist and Photoshop.

In summary, advertisement can be used in either good or bad ways, whether helpful or harmful depends on the creator of the advertisement. To be more precise, if the creator uses the advertisement in helpful way, such as showing his/her skills in advertises not just to gain 
incomes, it would be fine. But if the creator uses advertisement in a misleading just to sell the counterfeit products to consumers, it should not be allowed ideas were good, but you need to explain them in details. You need to start to think how to diversity the vocabulary used in the essays. 